\title{
A PAISAGEM SONORA EM A FACE DO ABISMO
}

\author{
THE SOUNDSCAPE IN A FACE DO ABISMO
}

Recebido: 30/10/2020 Aprovado: 04/01/2020 Publicado: 10/01/2021

DOI: $10.18817 /$ rlj.v4i02.2401

\author{
Gérson Luís Werlang ${ }^{1}$ \\ Orcid id: https://orcid.org/0000-0002-7449-0706 \\ Viviane Aparecida Pandolfo Debortolli2 \\ Orcid id: https://orcid.org/0000-0002-2805-0224
}

\begin{abstract}
Resumo: Este artigo analisa a paisagem sonora no romance $A$ Face do Abismo, de Charles Kiefer. A narrativa, traçada pela perspectiva de dois narradores diferentes, costura os 82 anos de existência de uma pequena cidade no interior do Rio Grande do Sul, colonizada por alemães, que some debaixo das águas após a construção de uma barragem. Por meio dos diferentes pontos de vista do texto, é possível verificar as transformações sonoras ocorridas no espaço e época da narrativa. O conceito de paisagem sonora utilizado para embasar esta análise provém dos estudos de Schafer (2011) e de Werlang (2011) e é utilizado para demonstrar a configuração da paisagem sonora no romance.
\end{abstract}

Palavras-chave: Paisagem sonora. Literatura. Charles Kiefer.

Abstract: This essay analyzes the sounscape in the novel A face do abismo (The face of the abyss). The narrative, drawn from the perspective of two different narrators, stitches the 82 years of existence of a small town in the interior of Rio Grande do Sul, colonized by Germans, which disappears under the waters after the construction of a dam. Through the different points of view of the text, it is possible to verify the sonic transformations that occurred in the space and time of the narrative. The concept of soundscape used to support this analysis comes from the studies by Schafer (2011) and Werlang (2011) and is used to demonstrate the configuration of the soundscape in the novel.

Keywords: Soundscape. Literature. Charles Kiefer

\section{Introdução}

O mundo é impregnado de sons, desde o som das águas, do vento, das vozes humanas, dos sons de cada espécie animal, até aqueles provindos de instrumentos musicais ou pós-revolução industrial. O estudo dos diferentes tipos de sons de acordo com o lugar e época é objeto de estudo do pesquisador e musicologista Murray Schafer (2011), que criou o termo paisagem sonora para se referir aos sons que compõe um ambiente. Presentes em diferentes espaços, esses

\footnotetext{
${ }^{1}$ Doutor em Letras pela Universidade Federal de Santa Maria - Brasil. Realizou estágio pós-doutoral em Educação Musical na Universidade Federal de Santa Maria - Brasil. Professor do Departamento de Música, da Pós-Graduação em Música e do Programa de Pós-Graduação em Letras da UFSM. Doutor em Letras e Mestre em Música.

${ }^{2}$ Mestre em Letras pela Universidade Federal de Santa Maria. Professora efetiva na rede estadual do Rio Grande do Sul.
} 
sons apresentam particularidades e podem ser sons naturais ou produzidos de alguma forma. A paisagem sonora seria, então,

o conjunto de sonoridades presentes em um determinado local, seja ele um espaço pequeno (um cômodo de casa, uma sala, etc.) ou um espaço amplo (uma cidade, uma floresta, os oceanos). Cada um desses ambientes possui um conjunto de sons que lhes são próprios, partes integrantes de sua constituição (DEBORTOLLI e WERLANG, 2020, p. 257).

Alterações sonoras foram registradas ao longo do processo de evolução da humanidade e cada espaço apresenta uma paisagem sonora específica, embora seja possível estabelecer sons comuns a lugares comuns, como os sons típicos das fazendas, por exemplo. Não é difícil perceber as mudanças sonoras nos sons urbanos contemporâneos, se comprados aos sons possíveis às cidades do século XVIII ou XIX. Essas peculiaridades sonoras influenciam a vida das pessoas, de modo que conceitos de paz e harmonia normalmente são associados a paisagens sonoras calmas, mais silentes, em oposição a paisagens sonoras de balbúrdia, que geralmente são associadas à ideia de stress e ansiedade.

Não é diferente no campo literário, o qual, muitas vezes, apresenta enredos que se passam em espaços e ambientes estruturados por meio de descrições explícitas ou subentendidas da paisagem sonora. Assim, a paisagem sonora na literatura pode ser entendida como um elemento diegético integrante do espaço e do ambiente. Observando a presença e os efeitos que os elementos sônicos produzem na literatura, o músico e pesquisador Gérson Werlang (2011) transpôs os estudos de Murray Schafer (2011), provenientes da acústica, para o domínio da literatura, os quais embasaram esta análise.

O propósito deste artigo é analisar a paisagem sonora no romance $A$ Face do Abismo, do escritor gaúcho Charles Kiefer, evidenciando as alterações sonoras ocorridas ao longo de oitenta e dois anos (entre 1903 e 1985) em San Martin, cidade vizinha a Pau-d'Arco, condado geográfico de Kiefer e que, segundo o próprio autor, equivale à sua terra natal, Três de Maio, na região do Alto Uruguai do Rio Grande do Sul. A narrativa conta histórias de alguns dos moradores de San Martin durante as oito décadas de existência da cidade, desde quando foi fundada, após o extermínio de uma aldeia indígena, passando pela chegada de pouco mais de uma dúzia de colonizadores alemães que deram início ao povoado que depois se transformou em cidade industrializada, com linha de trem e barragem hidrelétrica, a qual acaba por 
colocar fim à cidade. Os relatos das vidas nessa cidade são repletos de sonoridades, de forma que é possível traçar um panorama dessas mudanças, associando-as à história da humanidade, bem como observar a interferência da paisagem sonora nas ações dos personagens, além de verificar a percepção de narrador e personagens sobre os sons que compõe a paisagem sonora diegética.

\section{A paisagem sonora em A Face do Abismo}

Figurativamente, o romance $A$ Face do Abismo pode ser imaginado como uma alegoria da evolução da sociedade, a qual surgiu em meio a guerras e dizimação de povos, até chegar à industrialização. Cada fase desse ciclo teve suas particularidades sonoras, de modo que o estudo da paisagem sonora pode se configurar em fator importante para se determinar costumes, cultura e usos dos povos em diferentes épocas e locais. Como espaço e ambiente, a paisagem sonora é um dos muitos recursos utilizados em literatura para fazer com que o texto se pareça com a realidade, seu objeto de representação em textos realistas. Para Rosenfeld (2014)

A criação de um vigoroso mundo imaginário, de personagens "vivas" e situações "verdadeiras", já em si de alto valor estético, exige em geral a mobilização de todos os recursos da língua, assim como de muitos outros elementos da composição literária (...) (ROSENFELD, 2014, p. 37).

Dentre tais elementos está a paisagem sonora que, neste caso, transfigura as alterações sônicas no espaço com o qual tem relação e que advém inicialmente da criação de um povoado onde primitivamente havia só mato, e posteriormente se transforma em vilarejo e depois em cidade industrializada. Embora o tema da história não seja a sonoridade do local, é impossível não observar as variações da paisagem sonora diegética, analogamente à modificação da sociedade.

San Martin desmembrou-se de Pau'-d'Arco e é palco de uma narrativa nãolinear, contada a partir de dois tipos diferentes de narrador: um em terceira pessoa e outro, uma narradora-personagem, cujas falas em sua maioria advém de antigos relatos de outro personagem que morrera anos antes. Esse tipo de recurso aparece no romance como estratégia de criação literária. Para Anatol Rosenfeld "somente no gênero narrativo podem surgir formas de discurso ambíguas, projetadas ao mesmo tempo de duas perspectivas: a da personagem e a do narrador fictício" (ROSENFELD, 2014, p. 25). Por meio desse recurso, é possível observar diferentes 
aspectos sobre um mesmo episódio, diferentes percepções sobre a mesma paisagem sonora.

Alberta Zeller, filha de uma das mulheres que primeiro chegaram em San Martin é a narradora personagem que conta ao neto as histórias dos moradores da cidade na véspera do alagamento, em sua última noite na cidade natal. Deve-se notar que os relatos que faz são, em sua maioria, frutos das narrativas que ouviu da mãe e que, por vezes não condizem com a versão expressa na perspectiva dada pelo narrador em terceira pessoa, que é quem revela mais claramente algumas coisas que Alberta desconhece, como o fato de ela ser fruto do relacionamento extraconjugal que a mãe tivera com seu aparente inimigo, José Tarquino.

José Tarquino foi o fundador de San Martin; casou-se com uma das alemãs que chegaram para colonizar o povoado recém formado, mas que ficou viúva logo que chegou à vila. Com ela teve um filho, Gumercindo, que lutou ao lado do pai em guerras e revoluções. Quando idoso, Gumercindo comandava um programa na rádio local, onde leu, em 23 de março de 1979, o documento que oficializaria o fim de San Martin. A leitura do ofício gerou alvoroço na cidade, que culminou com uma passeata e com a morte do presidente do Sindicato dos Trabalhadores Rurais. Evidencia-se que, assim como a cidade foi fundada à base de assassinatos, quando seu fim foi anunciado também ocorreu uma morte, que se deu no mesmo lugar das anteriores, pois o presidente do sindicato foi morto exatamente no local em que setenta e seis anos antes o pai do Intendente fundara a cidade.

Em aspectos gerais, algumas das situações expressas na trama remetem à ideia da intertextualidade que sempre existiu na literatura. Um deles diz respeitos às referências à Bíblia, por exemplo, segundo a qual a noção de face do abismo existiu antes mesmo da criação do mundo. De acordo com o texto cristão, o livro do Gênesis: "No princípio, Deus criou os céus e a terra. A terra era informe e vazia. As trevas cobriam o abismo, e o Espírito de Deus movia-se sobre a superfície das águas" (BÍBLIA, 1982, p. 3), e a partir de então Deus ordenou que se fizesse a luz e em seguida algo que separasse as águas, criando dessa maneira o mundo.

Concepção análoga está presente no romance de Kiefer que traz na epígrafe essa citação do livro de Gênesis. No entanto, a simbologia não é apenas superficial, considerando que depois de criada a barragem também haveria só água no que fora San Martin. Ademais, José Tarquino fundou San Martin pela palavra, num ato simbólico, e é pela palavra que Deus criou o mundo: "O próprio Deus é 
verbo, é palavra. E o mundo foi criado pela palavra quando ele ordenou que a luz se fizesse e a luz se fez, iluminando as trevas que cobriam a face do abismo" (KIEFER, 1994, p. 26). Isso encontra respaldo no que SCHAFER (2011) postula quando afirma que "a palavra de Deus, originalmente, chegou ao homem pelo ouvido, e não pelo olho" (SCHAFER, 2011, p. 82).

A palavra é sonora, como sonoro é o som da água, sempre presente na história da humanidade, seja pelo viés bíblico ou científico. Schafer (2011) questiona: "Qual foi o primeiro som que se fez ouvir? Foi a carícia das águas" (SCHAFER, 2011, p. 33) ao lembrar que este som também é o primeiro ao qual o ser humano tem acesso, ainda no ventre da mãe, em relação análoga ao som do oceano, de onde teria surgido a primeira espécie de vida, de acordo com a teoria da evolução das espécies. Seguindo essa premissa, "o oceano dos nossos ancestrais encontra-se reproduzido no útero aquoso da mãe e está quimicamente relacionado com ele" (SCHAFER, 2011, p. 33). Em A Face do Abismo, é a água que vai fazer desaparecer a cidade de San Martin da face da terra, em outra correspondência bíblica quando esta apresenta, também no livro de Gênesis ${ }^{3}$, o episódio do dilúvio. É válido ressaltar a passagem em que Deus ordenou, também pela palavra, a Noé, que criasse uma arca e nela pusesse casais de todas as espécies de animais para a criação de um mundo novo a partir de uma inundação. Depois que todas as espécies de animais estavam salvas na arca, fez chover quarenta dias e quarenta noites a fim de alagar toda a superfície da terra, que estava tomada pela maldade. Não é muito diferente no romance de Kiefer, uma vez que San Martin carregava em si muito do que a bíblia condenava, como adultério, suicídio, assassinato, vícios, prostituição. Alegoricamente, da mesma forma que na Bíblia o dilúvio veio para lavar o mundo da maldade, em A Face do Abismo a inundação serviria para submergir o mal que fora feito naquela terra banhada pelo sangue indígena em sua criação.

O alagamento não é a única semelhança em relação ao dilúvio bíblico. $\mathrm{O}$ romance é dividido em quarenta capítulos; no episódio bíblico do dilúvio choveu durante quarenta dias. No dia seguinte ao final da narrativa de Kiefer a cidade fica submersa, como a terra ficou ao final dos quarenta dias de chova. Como a terra levou quarenta dias para desaparecer sob as águas, San Martin teve sua história dilatada em quarenta capítulos, antes de ficar submersa. Ao chegar ao final da

${ }^{3}$ BÍBLIA, 1982, p. 12 
leitura do romance, o leitor como que paira sobre a face das águas que cobrem a cidade. Figurativamente, é como se o leitor pudesse observar de fora (de cima) a cidade sumir sob as águas, semelhante à imagem do criador frente ao Dilúvio presente na Bíblia, ou durante a criação do mundo. Água e palavra, cada uma com seus sons, fazem parte da paisagem sonora em A Face do Abismo e é o som da água que permanece ao final da história.

O início do romance é sonoro, se passa já com a cidade consolidada e ocorre em um parágrafo longo em que há a descrição do ambiente psicológico, da paisagem sonora e do clima, juntamente com a citação dos badalos do sino da igreja. Depois de ter bebido demais, Gumercindo Rosas, filho de José Tarquino Rosas, acorda angustiado, sem conseguir entender de onde vem a opressão que lhe aperta o peito. Ao sair à varanda

Os vapores do rio embaciavam a paisagem, misturavam-se aos ruídos
miúdos que se faziam ouvir: um doloroso e plangente aboio, um latido
sincopado e um cantar de galo, a princípio solitário, mas logo repetido em
vários quintais da cidade. (...) Sabia que dali a pouco ouviria as badaladas
do sino da Igreja Matriz. Abriu a braguilha do pijama e mijou fartamente,
contando os minutos que faltavam para o primeiro repique do badalo no alto
do campanário. Quando soou, foi como se o fizesse dentro de sua cabeça
(KIEFER, 1994, p. 11).

Como é dito no texto, o vapor embaçava a paisagem, impedia que o local fosse visto com clareza, da mesma maneira que a angústia sentida pelo personagem não permitia que ele entendesse o que lhe incomodava. A paisagem natural/clima e a sensação a que o personagem está submetido são semelhantes, ambas refletem algo que não é límpido e estão misturadas à paisagem sonora. $\mathrm{O}$ romance todo toca nesse motivo da incerteza, da simulação, o que é evidenciado através de focos narrativos diferentes.

Os diferentes sons e os adjetivos utilizados para descrever o canto estão em conformidade com a paisagem e com a sensação negativa que aflige Gumercindo, pois tudo isso compõe o ambiente melancólico descrito na cena. Quanto ao sino da igreja, percebe-se que ele é tradicional no lugar. Mais do que isso, Schafer (2011) assevera que

O sinal sonoro mais significativo da comunidade cristã é o sino da igreja. Em um sentido bem verdadeiro, ele define a comunidade, pois a paróquia é um espaço acústico circunscrito por sua abrangência. $O$ sino é um som centrípeto; atrai e une a comunidade num sentido social, do mesmo modo que une homem e Deus (SCHAFER, 2011, p. 86). 
Em meio àquela sensação que o deixava desorientado, Gumercindo passa a recordar de seu casamento com Laura, em 1926. Ao rememorar o dia do casamento, as recordações do personagem se distanciam da atmosfera triste na qual acordara. Memórias positivas despertam lembranças sensoriais e auditivas positivas; o narrador descreve as músicas e danças que foram tocadas e dançadas na festa, o que sinaliza para as características da sociedade que estava se formando.

Schafer (2011) acredita que a sonoridade de um local revela muito sobre ele. De acordo com o autor "o ambiente acústico geral de uma sociedade pode ser lido como um indicador das condições sociais que o produzem e nos contar muita coisa a respeito das tendências e da evolução dessa sociedade" (SCHAFER, 2011, p. 23). Nesse sentido, a mesma cerimônia evidencia ainda costumes da festa, em relação às músicas e às danças.

Depois do almoço, da cerveja, do vinho e dos sucos de maracujá, guaraná, limão e framboesa, os noivos dançaram valsas, marchas, polcas e quadrilhas com os pais, os tios, os primos, os padrinhos e os amigos, sob os acordes de um conjunto vindo da cidade, composto por um violinista, um contrabaixista, um acordeonista e um flautista (KIEFER, 1994, p. 14).

Ao demonstrar a composição da banda e das danças é possível vislumbrar os vestígios do percurso histórico da presença da música em comunidades do interior do Rio Grande do Sul. Além do tipo de música tocada na festa, há a queima de fogos de artifícios, que neste caso são usados em comemoração ao casamento. "Fechou os olhos marejados e foi como se voltasse à festa de casamento em Pau'dArco. Os fogos de artifícios espoucavam, espantando os cães e as crianças, ecoavam na mataria" (KIEFER, 1994, p. 13). Já no capítulo quinze, há outra recepção dos sons produzidos pelos fogos de artifíci; Alberta Zeller, personagem que narra ao neto a história da cidade, conta o episódio dos tiros na noite do nascimento de Gumercindo a partir do que ouvira de sua mãe, Millena Zeller, já que a própria Alberta nasceu somente dezoito anos depois do ocorrido.

(...) José Tarquino quis fazer grande aquele momento, torná-lo inesquecível, do tamanho talvez de sua alegria, preservar o tempo cavalgando o próprio tempo através da aldeia, atirando para o alto sem saber que até os tiros já eram fumaça, ecos na memória do revólver. Sim, foi um atropelo medonho, acordados pelos tiros, os colonos pensaram tratar-se de um ataque indígena. $\mathrm{O}$ ataque que eles haveriam de esperar por dezenas e dezenas de anos e que nunca ocorreria (KIEFER, 1994, p. 68). 
Intriga o fato de um narrador-personagem saber o que passava na cabeça de outro personagem ao falar a respeito de um acontecimento que ela sequer presenciou e que ocorreu quase duas décadas antes de seu nascimento. Nesse caso, é possível observar os rastros deixados pelo autor, pois é dado ao leitor saber a possível intenção do personagem num comentário que o próprio narrador não teria condições de fazer. É o que Booth (1980) defende em sua teoria do autor implícito, quando diz que

Não podemos deixar de notar o artifício, quando o autor nos diz aquilo que, na chamada vida real, ninguém poderia saber. Na vida real não nos é dado conhecer ninguém através de sinais internos inteiramente fidedignos a não ser a nós próprios; e, mesmo assim, o conhecimento que a maioria de nós tem de si próprio é muito parcial (BOOTH, 1980, p. 21).

A questão dos tiros como representação do medo é expressa também no segundo capítulo do livro, quando apresenta o massacre da aldeia indígena, a qual foi exterminada para que San Martin fosse fundada. O capítulo dois está situado no tempo no ano de 1903 e relata a formação do povoado e apresenta José Tarquino, homem cujo olfato e audição são tão apurados que se assemelham ao dos animais. $\mathrm{Na}$ verdade, sua condição de bugreiro 4 o faz ser um pouco selvagem. Para Schafer (2011), "quando o homem estava com medo dos perigos de um ambiente inexplorado, todo o seu corpo se convertia em ouvido" (SCHAFER, 2011, p. 45). Com José Tarquino acontece o mesmo processo:

Ouvidos atentos aos mínimos ruídos, cabeça empinada, anda mais sôfrego que a montaria, o bugreiro farejava, os lóbulos de seu nariz fremiam, o apuradíssimo olfato buscava distinguir na profusão de odores da mata 0 cheiro invulgar dos índios (KIEFER, 1994, p. 19).

O fragmento em destaque revela a importância da audição no ataque à aldeia, pois, nesse caso, ouvir era antes de qualquer coisa um mecanismo de defesa. Era através da audição que os homens do bando poderiam se manter afastados do que era perigoso, e já que não dispunham de uma ampla visão da aldeia, porque era noite e porque a mata era densa, os recursos do faro e da audição faziam o papel que os olhos não podiam fazer. No momento em que José Tarquino e os seus homens estavam a postos "o silêncio descera sobre a mata não

\footnotetext{
${ }^{4}$ Espécie de caçador de índios, chamado assim porque exterminava aldeias indígenas inteiras, embora fosse filho de uma índia.
} 
como o orvalho, mas de súbito, abrupto e imprevisto como um punhal repentino, e vibrava de expectativa, como quando a natureza inteira se aquieta na iminência dum temporal" (KIEFER, 1994, p. 19).

A sequência da cena apresenta uma grotesca mudança na paisagem sonora, pois ela passa de uma sonoridade bucólica à do combate. Imediatamente após o silêncio que desceu sobre a mata, o homem produziu o barulho apocalíptico da batalha. Para Schafer (2011), "embora a paisagem sonora natural fosse em geral silenciosa, era deliberadamente interrompida pelos ruídos aberrantes da guerra" (SCHAFER, 2011, p, 81). Ele reitera que

os exércitos condecorados para a batalha ofereciam um espetáculo visual, mas a batalha em si era acústica. Ao barulho dos metais que se entrechocavam cada exército acrescentava seus gritos de guerra e toques de tambor no intuito de amedrontar o inimigo. O barulho era um estratagema militar deliberado defendido pelos antigos generais (...) (SCHAFER, 2011, p. 80).

Nesse sentido, o principal elemento da guerra é sonoro. A batalha é convertida em sons, sejam eles de armas, de gritos, ou os produzidos em virtude da morte. A mudança abrupta na paisagem sonora a partir da introdução do episódio do extermínio da aldeia indígena é demarcada também porque o "bando circulou ao redor da aldeia aos gritos, comemorando a vitória da difícil batalha" (KIEFER, 1994, p. 20). Nota-se que o grito é usado, não só para pôr medo no inimigo, também como forma de comemoração, semelhante ao uso dos tiros de arma de fogo.

Na cena acima, o grito é colocado como forma de opressão. Grito também é linguagem. Da mesma maneira que o silêncio tem significados, o grito também tem. Nesse fragmento em especial ele revela o cunho opressivo porque logo após os homens destruírem a aldeia há a descrição de uma cena de estupro coletivo e assassinato praticado contra uma indiazinha. Após o fim da batalha e da comemoração pela vitória o silêncio havia se instalado novamente da aldeia. Então,

Súbito, numa voz que ecoou pelos grotões às margens do Uruguai, gritou alguém:

- Vejam!

Olharam todos na direção apontada, onde uma indiazinha tentava alcançar a mata (KIEFER, 1994, p. 20).

Porém, o silêncio pós-batalha não era o mesmo relatado pouco tempo antes, que foi comparado a um temporal por pressagiar uma tragédia. Era o silêncio brutal provindo da morte. Se o sangue derramado emitisse um som, era ele que seria 
ouvido. O silêncio era tanto que o grito do homem sedento pela cobiça sexual ecoou pelos grotões da mata. José Tarquino e seus homens haviam estabelecido seu poder sobre aquelas terras, e esse poder se revela no eco de seus gritos na mata cuja presença humana não era mais a indígena. Em outras situações se supõe a questão do eco como algo significativo, já que ele dá a ideia de algo que continua. Ele, que para Orlandi (2007) é "repetição, não-finitude, movimento contínuo. Também fresta para ouvi-lo. Som" (ORLANDI, 2007, p. 33).

Aqui interessa evidenciar um aspecto sublinhado por Schafer (2011), de acordo com o qual há diferença na recepção do som produzido logo após um momento de silêncio e outro que não substitui um momento silencioso ${ }^{5}$. Então, considerando que o grito surgiu em meio ao silêncio provocado pela morte, provavelmente a reação da menina tenha sido de pavor. Após ser violentada sexualmente pelos homens do bando, com exceção do chefe, a menina foi executada com um tiro na cabeça. Na sequência

\footnotetext{
José Tarquino, que a tudo assistira calado e imóvel, desceu do cavalo quase sobre o corpo inerte, abriu as calças e, antes de explodir numa gargalhada que ecoou distante, lavou o rosto ensanguentado da indiazinha com um forte jato de urina (KIEFER, 1994, p. 20).
}

A cena acima reforça a tese da representação do poder e da opressão através de gritos e gargalhadas. É o som que anuncia a aniquilação. Em configuração análoga, o som intenso e potente do grito ou da gargalhada pode ser aproximado em contexto mais amplo a outros sons fortes que imprimem a ideia de superioridade. Schafer (2011) chega a afirmar que "se os canhões fossem silenciosos, nunca teriam sido utilizados na guerra" (SCHAFER, 2011, p. 115).

Embora os colonizadores de San Martin pudessem ficar escandalizados com a brutalidade da matança, caso soubessem da verdade, em momento algum eles pareceram julgar como errado o massacre, de forma que as aventuras do bando de José Tarquino, que se repetiriam em outras guerras, eram vistas como fatos heroicos,

Então, enquanto falava, tentando embelezar a narrativa com a descrição do sol sobre as árvores, em meio à cerração do rio, o sol radiante atingindo as minúsculas gotículas de orvalho, ou com a descrição minuciosa das flores silvestres e dos cantos dos pássaros, eu via apenas os corpos mutilados, o

${ }^{5}$ SCHAFER, 2011, p. 351 - 358 
sangue, a dor e a agonia das mulheres e crianças guaranis (KIEFER, 1994, p. 24).

Percebe-se o uso do canto dos pássaros como uma tentativa deliberada de tornar a cena mais bela, o que na realidade seria inverossímil, pois é muito pouco provável que eles iriam permanecer cantando em meio a tiros e fogos, num ambiente de guerra. Tal acepção encontra eco nos postulados de Schafer (2001), para quem

as canções dos pássaros sempre hão de sugerir esta delicadeza de sentimentos, e eu gostaria de ir mais além e afirmar que elas aparecem na música em deliberada contradição com a brutalidade e os acidentes da vida exterior (SCHAFER, 2011, p. 155).

É incontestável que o canto dos pássaros é contrário à barbárie da guerra. Além disso, Alberta Zeller faz o relato do massacre como se tivesse ocorrido durante o dia, e ele teria acontecido, de acordo com a versão do outro narrador, durante a noite, conforme se observa no fragmento a seguir:

Fazia uma noite luminosa, um céu coalhado de estrelas, a lua esparzia filetes de luz gelada, que se refletiam nas ondulações das águas e nas minúsculas gotículas de orvalho dependuradas nas folhas das árvores e nos talos de capim (KIEFER, 1994, p. 19).

Alberta segue a narrativa contando ao neto como se deu o início da colonização e a derrubada da primeira árvore a machado, que acabou por fazer a primeira vítima do povoado. A alteração na paisagem sonora nesse ponto da narrativa introduz um elemento novo, que é a derrubada das árvores. Detalhes sônicos desse processo são destacados por Schafer (2011)

As dificuldades dos primeiros colonos em lidar com a floresta e seus anseios por espaço e luz solar logo produziu outra nota tônica: a de corte de madeira. Em princípio, foi o machado do lenhador que se ouviu ressoar para além da espaçosa clareira. Mais tarde foi a trançadora, e hoje, é o emaranhado de serra elétrica que ecoa pelas comunidades florestais cada vez menores (...) (SCHAFER, 2011, p. 45).

Em A Face do Abismo, a partir do momento que os colonos chegaram para fixar morada em San Martin eles estabeleceram mudanças no local, tanto estruturais, como o desmatamento, a construção do cemitério, da igreja e das casas, como alterações sonoras, pois trouxeram com eles suas músicas, seus costumes, sua língua, que transformou a sonoridade própria da mata fechada em um ambiente povoado, e com o passar do tempo, em cidade (com indústrias, automóveis e até 
linha férrea). Essa mudança social e sonora que ocorreu ficcionalmente em San Martin aproxima-se do que aconteceu na história da humanidade e que foi descrita por Schafer (2011)

Os dois grandes fulcros de mudanças da história da humanidade foram a substituição da vida nômade pela agrária, ocorrida entre dez e doze mil anos atrás, e a transição da vida rural para a vida urbana, que vem ocupando os séculos mais recentes. À medida que este último desenvolvimento vem ocorrendo, os vilarejos têm-se transformado em cidades e as cidades têm-se expandido para cobrir grande parte daquilo que era anteriormente o mundo rural (SCHAFER, 2011, p. 85).

A introdução da vida agrária em ambiente de natureza e a substituição desta pela vida urbana é alegorizada pela chegada dos alemães, que transformaram o lugar num povoado e com o passar do tempo em uma cidade. Os sons do primeiro dia de San Martin podem ser verificados a partir da perspectiva de Alberta Zeller: "Sim, certamente foi naquele primeiro dia na terra nova, cercada de animais, de árvores e de ruídos ameaçadores, que minha mãe benzeu pela primeira vez" (KIEFER, 1994, p. 26). Nota-se que cada um desses elementos produz uma sonoridade própria, cada animal tem seu som característico, bem como há diferença nos sons emitidos por cada tipo de árvore, especialmente quando expostas ao vento. Em termos diegéticos, o fragmento configura-se, num certo grau, em um registro da paisagem sonora do povoado em 1903, ainda que sob a perspectiva de um narrador que apenas conta o que ouviu de outra personagem.

Merece destaque a paisagem sonora de uma época em que o principal meio de transporte era o de tração animal, e que foi modificado à medida que outras formas de deslocamento foram criadas. A sonoridade de San Martin passou por várias transformações, e uma delas é a substituição do bater dos cascos do cavalo, que passam a estar basicamente na cavalaria montada da brigada militar, não mais o casco contra o chão de terra, mas contra o calçamento. Após a festa de casamento, Gumercindo e Laura ainda na primeira metade do século XX

\footnotetext{
seguiram os dois calados e pensativos pela senda escura, o bate-que-bate da montaria atiçando o silêncio, fazendo os pequenos animais da mata se espantarem e os pássaros escondidos nas galharias alçarem voo sobre os paus-d'arco, louros, cedros, timbaúvas, grápias e canjaranas (KIEFER, 1994, p. 14).
}

Há outra diferença sonora no enredo que precisa ser destacada: embora o tropel do cavalo seja algo bastante conhecido e recorrente até hoje na 
região do Alto Uruguai do Rio Grande do Sul (onde geograficamente está localizada a fictícia cidade de San Martin) há uma óbvia diferença no som produzido quando o animal está se deslocando sobre a terra ou sobre a calçada pavimentada, bem como quando vem acompanhado do rangido das rodas de carroças. As reflexões de Schafer (2011) a respeito desse tema dão conta de que

Um dos sons fundamentais mais influentes das primeiras paisagens sonoras urbanas deve ter sido o tropel dos cavalos, audível em toda parte, nas ruas pavimentadas de pedra, e diferente do cavo ruído dos cascos em campo aberto (SCHAFER, 2011, p. 98).

Isso se verifica em A Face do Abismo, bem como se observa a teoria de Orlandi (2007), na defesa da ideia de que o silêncio precede a linguagem, e por extensão, o som ${ }^{6}$. Ou seja, tanto a linguagem quanto o som existem por causa do silêncio, quando há algo que quebra esse silêncio, e nesse caso é o tropel do cavalo.

Outros elementos sonoros são introduzidos no texto, como costumes e danças trazidas pelos colonizadores. A gênese das festas em solo gaúcho revela alguns aspectos que se percebe também na ficção.

Costumeiramente, havia bailes na campanha. Eles aconteciam nas estâncias, nas ramadas dos bolichos ou carreiras. As elites costumavam imitar os bailes europeus. Dessa forma, muitas danças ingressaram no pampa. Eram frequentes o minueto, a contra-dança, a polca, a valsa, a mazurca, o xote, a havaneira e outras.

Entretanto, o que mais se popularizou foi o fandango. No século XIX, o fandango era uma espécie de baile com sapateados alternados com canções, recitadas e acompanhadas de viola. As danças eram recriações populares dos povoadores "primitivos paulistas, mineiros e lagunenses, com as danças dos açorianos e dos indígenas", além da influência africana. Chamavam-se: anu, balaio, bambaquerê, benzinho-amor, candeeiro, cará, chimarrita, xará, chico-puxado, chico-de-roda, feliz-meu-bem, joãofernandes, meia-canha, pagará, pega-fogo, queromana, recortado, retorcida, sarrabalho, serrana, tatu, tirana.

Os ranchos onde se promoviam as danças eram chamados bailantas.

$\mathrm{E}$, com o passar do tempo, entre os gaúchos, fandango passou a ser sinônimo de baile, mesmo que raramente dancem de forma espontânea com sapateados e recitações, e, sim, em pares enlaçados (GOLIN, 2001, p. $67)$.

Festas semelhantes se espalharam pelo Rio Grande do Sul, fazendo-se presentes também em comunidades e pequenas cidades do interior. Isso ocorre ficcionalmente também em San Martin e Pau-d'Arco, onde, em meio a esses

${ }^{6}$ Orlandi, 2007, p. $30-31$. 
costumes, chegaram "aqueles alemães rosados, bebedores de cerveja, comedores de batata, com suas músicas, seus costumes e seus bailes de Kerb" (KIEFER, 1994, p. 152). Nesse caldo em que se misturam costumes indígenas, africanos, açorianos, alemães, italianos, entre outros, e também de outras regiões brasileiras, é que se formou o Rio Grande do Sul e sua cultura.

O primeiro registro de música no povoado se deu um ano depois de sua fundação, durante a festa do primeiro aniversário de San Martin, mesmo que o romance apresente antes a festa de casamento de Gumercindo e Laura, em 1926. Pelos relatos dos narradores, sabe-se que Millena Zeller (mãe de Alberta, uma das narradoras, e que se envolveria com José Tarquino) foi à festa, assim como José Tarquino e Herta Muller, que naquela noite estaria se despedindo do luto que guardara pela morte do marido. Importa o fato de Millena estar na festa porque é ela quem contou para Alberta as coisas que esta narra ao neto. Por conseguinte, aos olhos dela equivalem os olhos do leitor nos capítulos narrados por Alberta.

Embora Millena não tenha percebido, tanto José Tarquino quanto Herta estavam com seus instintos à flor da pele; ela porque tiraria o luto; ele, porque sentia necessidade de pertencer ao grupo, e já que não tinha descendência germânica se sentia ainda como um estranho. Ao chegar perto da festa José Tarquino ouve que "Um animal urrou distante, ele estacou. Reconheceu a fome naquele som rouco, e sentiu-se a própria onça, num meio estranho e hostil" (KIEFER, 1994, p. 34). Como uma forma de presságio, o timbre do som produzido pelo animal antecipa algo que está por vir. Há uma aproximação evidente entre a espécie humana e a onça, bem como um comparativo entre onça e destino. "A onça urrou outra vez, agora mais perto" (KIEFER, 1994, p. 34). José Tarquino, como exímio caçador que era, identificou de ouvido a espécie de animal que emitira o som, bem como a fome da qual padecia e sentiu-se a própria onça, à medida que ele também se percebia como um estranho no vilarejo. A fome da qual ele padecia não era de comida, era de pertencimento, de fazer a vida ao lado de uma mulher. O reconhecimento da fome pelo tipo de som emitido pela onça encontra respaldo na pesquisa de Schafer (2011), o qual afirma que alguns animais emitem expressões vocais diferentes, de acordo com o que estão sentido. Embora se refira aos leões, Schafer (2011) explica que

Há um "grito de prazer", observado principalmente nos leões em cativeiro, que se inicia com o aparecimento do tratador. O som produzido quando a fera se encontra sozinha, alimentada e tranquila é um rosnado suave e 
profundo. No entanto no momento em que a presa é apanhada os leões emitem um breve e amedrontador ladrido de ferocidade. Por fim, há o verdadeiro rugido, normalmente ouvido à noite, o que é raro à luz do dia. Às vezes, quando rugem, os leões mantêm a boca junto ao chão, o que intensifica a ressonância e a vibração da voz (SCHAFER, 2011, p. 66).

Diante do exposto no argumento acima, é realmente possível o personagem ter percebido através da audição do tipo de som emitido pela onça que ela estava com fome. A expressão é novamente usada na mesma cena, só que desta vez em relação a Herta. Por conta disso, tanto ela quanto José tiveram, na mesma cena, a simbolização da onça faminta representando o que sentiam. "Herta Muller sabia que o Destino se aproximava, urrando como uma onça faminta, pisoteando o lodo como um cavalo xucro na noite mesma em que desvestira do luto?" (KIEFER, 1994, p. 36). Além do mais, há a personificação do Destino, que se aproximava como uma onça faminta, ou seja, há o adiantamento, através de elementos da natureza, de que algo muito importante está por acontecer, semelhante a quando a natureza emudece pressagiando a tempestade. Nos fragmentos em destaque o som dos animais é utilizado para representar a intensidade do momento. Em meio a esse ambiente, José Tarquino se desloca à festa de aniversário do povoado de San Martin, em que a música cumpre papel determinante.

\begin{abstract}
As chuvas semanais, as rodas das carroças, os cascos dos bois e cavalos haviam resultado em poças d'água e lama. Irritado, chegou a pensar em não ir à festa, mas o sofrido acorde de uma harmônica atravessou o ar quente da noite e o arrastou, acorde que haveria de lembrar com saudade até $\mathrm{o}$ final de seus dias, não fossem aquelas notas tristes e indecisas seu destino teria sido outro, pois basta um nada para não ser o que seria neste mundo de tantas trilhas e picadas, de caminhos que levam a boçorocas e campinas (KIEFER, 1994, p. 34)
\end{abstract}

A música foi a responsável por fazer com que o antigo bugreiro não desistisse de ir à festa. O som produzido pela harmônica, também conhecida por gaita, o impeliram a ir, como se também ela pressagiasse que naquela noite o destino de José Tarquino seria definido. Embora ele vá sentir saudade dos acordes que ouviu na noite da festa, a vida que teve com Herta, cuja aproximação se delineou ali, não foi das mais agradáveis, pois apenas um ano depois ela teve problemas durante o parto e enlouqueceu. Interessante é que a música tocada não era alegre, e ele foi atraído justamente pela melancolia sonora. Quando ambos os personagens já estavam na festa, a música ocupa um lugar elementar, pois é ela, e exatamente ela quem efetiva a aproximação dos dois. 
Não terá pressentido a mulher renascida que a harmônica parou de tocar não porque ele acabara de chegar à festa, mas porque o momento era por demais solene e exigia silêncio, um silêncio profundo e reverente? Para os outros, Kiefer interrompeu a valsa porque era muita audácia do estranho vir sem ser convidado, mas não para ela. Para Herta Muller era a oportunidade que o Destino lhe oferecia, quem sabe a última, e por isso ela não titubeou. - Fui eu que o convidei - ela disse.

E, voltando-se para Gustav Kiefer, pai de Wolfgang, que viria a ser secretário de administração de Gumercindo, filho de José Tarquino, prosseguiu:

- Continue a música que eu quero dançar (KIEFER, 1994, p. 37).

O momento solene que exigiu silêncio era a decisão de um destino. Tudo o que aconteceu depois na narrativa foi consequência do que ocorreu naquela festa. Dessa forma, o destino da cidade de San Martin é traçado exatamente pela música, ao ganhar a aura quase de um espírito que induz os personagens ao caminho que devem seguir. Talvez, se a música não tivesse tocado o coração de José Tarquino, ele jamais teria se casado com Herta, jamais teria o filho Gumercindo e talvez não tivesse se envolvido com Millena. Assim, o divisor de águas na narrativa foi a música. Isso se deu também pela perspectiva de Herta. Dessa forma, é possível perceber que a paisagem sonora não só influencia as ações dos personagens como também contribui para a evolução da narrativa, já que a sonoridade, especialmente aqui, não é meramente um pano de fundo.

Verifica-se que a música transmutara-se em outra coisa, em alguma força estranha capaz de decidir o destino de uma cidade inteira. $O$ poder quase sobrenatural atribuído à musica nessa parte do romance faz dela um elemento chave no enredo. Singular também é o tipo de música tocada no momento em que José Tarquino chega, já que a valsa foi, por muito tempo, considerada uma dança vulgar e imoral, por ser dançada com os corpos se tocando.

Tivesse o Kiefer se recusado a tocar e o que é não seria, talvez nem a barragem fosse construída, porque destruir um único fio da amarração da vida é desmontar o tempo e reordená-lo. Num instante, que a todos pareceu infinito, enquanto o músico se decidia, criaram-se infinitos futuros, caminhos imbricados em caminhos, até que a primeira nota soasse e tudo corresse para o rumo que veio a dar na praça da matriz e na leitura do ofício (KIEFER, 1994, p. 37).

Há uma clara sensação de suspensão de tempo gerada pelo silêncio que desceu sobre o salão de baile entre o momento em que o músico parou de tocar, porque Tarquino havia chegado, e o momento em que Herta o anunciou como seu 
convidado. No romance, os ecos da decisão tomada naqueles poucos segundos se estenderiam por muitos anos. A retomada do transcurso do tempo se dá quando a música volta a ser tocada. A imagem construída nesse episódio mostra um indubitável congelamento de tempo, equivalente àquelas criadas no cinema. Talvez essa seja a cena que mais profundamente estabelece a noção sônica e visual do que é narrado. Possivelmente, em nenhum outro momento do romance se vê e se ouve com tanta intensidade o que está acontecendo com os personagens, tamanha é a influência dessa passagem na trama, e a base de tudo isso se dá através da música, pois "os dois dançaram a noite inteira como se estivessem sozinhos, sob os olhares incrédulos e envergonhados, ele era homem, solteiro, na força da idade, e ela mulher, viúva e mãe de três filhos" (KIEFER, 1994, p. 37). Em A Face do Abismo, o mecanismo que efetivou a aproximação entre os dois é a dança, oportunidade em que os personagens puderam deixar claras suas intenções diante dos demais moradores do vilarejo.

A cena da dança foi narrada duas vezes; a descrita acima é pelo narrador onisciente. A transcrição a seguir apresenta o que seria a perspectiva de Herta, mas que foi descrita por Millena e que no presente da narrativa Alberta conta o neto.

\footnotetext{
Dançaram os dois a noite inteira, e as brasas amortecidas reacenderam. A ela não importava que as mãos que acariciavam a sua carne tivessem atirado sobre os índios. Não, nada importa a uma mulher que precisa optar entre a solidão e a própria vergonha do ostracismo. Enfrentaria os homens e as mulheres de sua raça, abandonaria o vilarejo se preciso fosse, mas não abriria mão da chance de ser feliz (KIEFER, 1994, p. 37).
}

Merece destaque no fragmento acima o fato de que Alberta Zeller faz novamente um julgamento do que outra personagem pensa, numa cena que ela não presenciou. As reflexões externadas por ela são, na verdade, vestígios do autor implícito. A passagem do texto ficcional acima condiciona o leitor a entender o que os personagens pensavam enquanto dançavam. Nessa parte é possível aplicar a teoria de Booth (1980) quanto ao autor implícito, pois o capítulo é narrado por Alberta e apresenta julgamentos que ela jamais seria capaz de fazer, mas aos quais o leitor acaba tendo acesso. Dessa forma, quem teria condições de saber ou supor o que os personagens pensavam enquanto dançaram não é um narradorpersonagem e sim o autor implícito, que, segundo Booth (1980) sempre se revela. Para ele "(...) a presença do autor será óbvia sempre que ele entrar ou sair da mente dum personagem - quando 'desloca o seu ponto de vista' (BOOTH, 1980, p. 34)”. 
Em A Face do Abismo, as variações de espécies de animais que emitem seus sons característicos evidenciam o efeito sonoro proveniente das alterações no ambiente natural, decorridas pela ação do homem em estado de domínio sobre a natureza, que relegou alguns animais a espaços apenas de preservação ambiental. Assim como na realidade, no texto ficcional houve a urbanização do espaço e a prática de caça às onças. No romance em questão, só há referência aos sons das onças nos capítulos relativos ao início do século XX.

\title{
Considerações finais
}

Abrir o portal que dá acesso aos estudos da paisagem sonora é aceitar um exercício também de audição. De audição do que emerge do espaço e do que brota da subjetividade. Ativar um sentido que vai além dos tradicionais na percepção sensorial do texto ficcional, todos estes são elementos que a análise da paisagem sonora pode trazer para os estudos literários e que é possível observar no romance de Kiefer utilizado nesta análise.

Alguns elementos como a música integram a paisagem sonora das narrativas e passam a fazer parte delas. Mais do que isso, por vezes carregam em si a capacidade de evidenciar aspectos específicos das comunidades em que circulam. Isso já foi evidenciado por Schafer (2011) quando afirmou que

\begin{abstract}
A música é um indicador da época, revelando, para os que sabem como ler suas mensagens sintomáticas, um modo de recordar acontecimentos sociais e mesmo políticos. (...) o ambiente acústico geral de uma sociedade pode ser lido como um indicador das condições sociais que o produzem e nos contar muita coisa a respeito das tendências e da evolução dessa sociedade (SCHAFER, 2011, p. 23).
\end{abstract}

Em A Face do Abismo, a cena do baile em que José Tarquino dança com Herta Muller, e ambos são observados por Millena, é reveladora do potencial semântico da paisagem sonora, porque o próprio texto literário carrega em si a perspectiva de que toda a história da cidade poderia ter sido diferente se, por exemplo, o músico não tivesse seguido com a execução da música. Foi o efeito de uma decisão permeada pela tônica musical que traçou o destino de uma cidade inteira, que já vinha sendo descrita por motivos sonoros. O romance em questão aborda a sonoridade local desde o primeiro capítulo e permite ao leitor escutar os sons da cidadezinha até o final. 
Ademais, considerando a intertextualidade bíblica presente em $A$ Face do Abismo, é possível inferir que o evento da destruição da cidade através da criação da barragem é uma metáfora da remissão, por meio das águas, e essa passagem é sonora. Embora não seja possível ouvir, porque o presente da narrativa é a véspera da abertura da barragem, é fato que a inundação da cidade se daria, também, por meio do elemento sonoro. Assim como o primeiro som que se fez ouvir foi o ruído das águas, tanto na perspectiva científica quanto na religiosa a respeito da criação do mundo, o último som que se faria ouvir em San Martin seria o da água, a mesma que colocaria fim à cidade.

\section{Referências}

BÍBLIA SAGRADA, Org.: Pe. Francisco Costa. Aparecida: Santuário: 1982.

BOOTH, Wayne. A retórica da ficção. Lisboa: Arcádia - Tradução Maria Teresa H. Guerreiro. Coleção Artes e Letras, 1980.

DEBORTOLLI, Viviane Aparecida Pandolfo; WERLANG, Gérson Luís. A paisagem sonora como elemento constitutivo do conto "O Poncho", de Charles Kiefer. In: Eixo Roda, Belo Horizonte, v. 29, n. 1, p. 255-274, 2020.

GOLIN, Tau. O povo do pampa: uma história de 12 mil anos do Rio Grande do Sul para adolescentes e outras idades. 2. ed. Passo Fundo: UPF, 2001.

KIEFER, Charles. A face do abismo. 2. ed. Porto Alegre: Mercado Aberto, 1994.

ORLANDI, Eni Puccinelli. As formas do silêncio: no movimento dos sentidos. 6. ed. Campinas, SP: Unicamp, 2007.

ROSENFELD, Anatol. Literatura e Personagem. In: CÂNDIDO, Antônio. A personagem de ficção. 13. ed. São Paulo: Perspectiva, 2014.

SCHAFER, R. Murray. A afinação do mundo. 2. ed. São Paulo: UNESP, 2011.

WERLANG, Gérson Luís. A música na obra de Erico Verissimo: Polifonia, Humanismo e Crítica Social. Passo Fundo: Méritos, 2011. 